Servidoni, L.E., Silva, L.F.P., Santana, D.B., Rodrigues Neto, M.R., Lense, G.H.E., Ayer, J.E.B., Spalevic, V., Mincato, R.L. (2021): Monitoring of regeneration of native forest fragment impacted by fire. Agriculture and Forestry, 67 (4): 71-80. doi:10.17707/AgricultForest.67.4.07

DOI: 10.17707/AgricultForest.67.4.07

\begin{abstract}
Lucas Emanuel SERVIDONI ${ }^{1}$, Luis Felipe Pigatto Miranda SILVA, Derielsen Brandão SANTANA ${ }^{1}$, Manoel Ribeiro RODRIGUES NETO', Guilherme Henrique Expedido LENSE ${ }^{I}$, Joaquim Ernesto Bernardes AYER', Velibor SPALEVIC ${ }^{3,4}$ and Ronaldo Luiz MINCATO ${ }^{I}$
\end{abstract}

\title{
MONITORING THE REGENERATION OF NATIVE FOREST FRAGMENTS IMPACTED BY FIRE
}

\section{SUMMARY}

Forest fires have increased a lot in Brazil in recent years, causing air pollution, increased soil erosion processes with production of sediments, emission of greenhouse gases and overloading public health services, with severe environmental and socioeconomic losses. Therefore, the development of new analysis and mapping technologies for areas affected by fires is necessary and essential in this context of accentuated expansion of forest fires. Research monitoring flights were performed with an unmanned aerial vehicle to obtain RGB aerial images of a fragment of native forest affected by fire in July 2019. Thus, subareas were defined to define mapping patterns that can serve as algorithms for remote detection of areas affected by fires. Afterwards, land use were generated to monitor the evolution of the natural process of regeneration of the forest fragment. The studies identified that 0.77 ha was affected by the fire and that from August to November of the same year, the area was completely regenerated, and all remnants of the forest fire were eliminated. Thus, the work explains a strategic alternative for reducing, combating, and monitoring forest fires. Furthermore, it also contributes as a tool for the preparation of recovery plans for areas impacted by forest fires.

Key words: Monitoring; Remote Sensing; Environmental Planning; Regeneration; Nature Conservation; Brazil.

\section{INTRODUCTION}

Global warming has increasingly raised the concerns of both state administrations and the scientific community in recent decades (Stefanidis \&

\footnotetext{
${ }^{1}$ Lucas Emanuel Servidoni, Luis Felipe Pigatto Miranda Silva, Derielsen Brandão Santana, Manoel Ribeiro Rodrigues Neto, Guilherme Henrique Expedito Lense, Ronaldo Luiz Mincato (corresponding author: ronaldo.mincato@unifal-mg.edu.br), Federal University of Alfenas, UNIFAL-MG, Alfenas, Minas Gerais, BRAZIL;

2 Joaquim Ernesto Bernardes Ayer, Brazilian Agricultural Research Company - EMBRAPA, Jaguariúna, São Paulo, and Paulínia University Center - UNIFACP, Paulínia, São Paulo, BRAZIL;

${ }^{3}$ Velibor Spalevic, University of Montenegro, Biotechnical Faculty, Podgorica, MONTENEGRO;

${ }^{4}$ Velibor Spalevic, University of Montenegro, Geography, Faculty Philosophy, MONTENEGRO.

Notes: The authors declare that they have no conflicts of interest. Authorship Form signed online.

Recieved:04/10/2021

Accepted:26/11/2021
} 
Alexandridis, 2021). Climate change and global warming are expected to affect natural hazards like soil erosion, increased sedimentation and depositions in water reservoirs, flooding, and wildfires worldwide (Hysa et al., 2021; Spalevic et al, 2020; Hysa et al., 2020; Chalise et al, 2019; Spalevic et al, 2013). Forest fire is understood as any uncontrolled fire that affects vegetated areas, because of natural or anthropogenic influences, which negatively impacts animal and plant species and human lives. When criminal or without proper management, it causes negative socioeconomic and environmental effects (Biazatti et al., 2020).

Increased air pollution, reduced soil fertility, increased rates of soil erosion and runoff are among the harmful effects of forest fires. In Brazil, fires are the main threats to environmental preservation areas and are most often premeditated by economic interests and, to a lesser extent, caused by acts of vandalism, recreational activities and the negligence of public control and inspection agencies (Tebaldo et al., 2013).

Fire risk varies with environmental conditions and characteristics of vegetation types. In other words, monitoring fires in a continental country like Brazil represents an arduous and extremely complex task, due to the logistical difficulties of the territorial extension and the diversity of forest formations. According to Bizatti et al. (2020), most forest fires are caused by human activity. These activities can be related to criminal acts or not. However, the impacts triggered by fires cause damage to the landscape and its elements (Eugenio et al., 2016).

Recently, in Brazil, wave of fires was recorded that endangered the Brazilian biomes in a generalized way, especially at the Cerrado (Savanna), the Pantanal and the Amazon. Such events are increasing more and more in the Brazilian territory, not only promoting environmental devastation at different scales, but also accelerating and accentuating climate change, negatively affecting the soil water regime and causing water scarcity, which generates insecurity and socioeconomic and environmental uncertainties (Sarra and Mülfarth, 2021).

The widespread use of geographic information systems and geoprocessing and remote sensing techniques allowed advances in methods, like images from unmanned aerial vehicles - UAV (Sestras et al, 2021; Felix et al., 2021; Sestras et $a l, 2020$ ), for mapping natural phenomena (Kalehhouei et al., 2021; Sestras et al, 2019; Stefanidis et al, 2021). Thus, these technologies are fundamental tools for the development of socioeconomic and environmental management plans, and even for the prevention and combat of forest fires and promoting the economic and environmental sustainability of populations dependent on forest resources. Thus, in countries with continental dimensions, such as Brazil, promoting the use of geotechnologies is essential for the successful mapping, prevention and monitoring of natural phenomena and disasters (Girona-García et al., 2021).

The objective of this work was to present, in the degradation scenario of the main Brazilian biomes, the patterns for detecting forest fires in images obtained by the UAV and to monitor the regeneration of native forest in an environmental preservation area affected by fires. 


\section{MATERIAL AND METHODS}

The study was carried out in a permanent preservation area of 2.81 ha in the Santa Clara Unit of the Campus Headquarters of the Federal University of Alfenas. The area belongs to the Córrego do Cemitério hydrographic sub basin, a tributary of the Furnas Hydroelectric Power Plant reservoir (Figure 1). The sub basin is located at the urban perimeter of the Alfenas Municipality, southern Minas Gerais State, South-eastern Brazil.
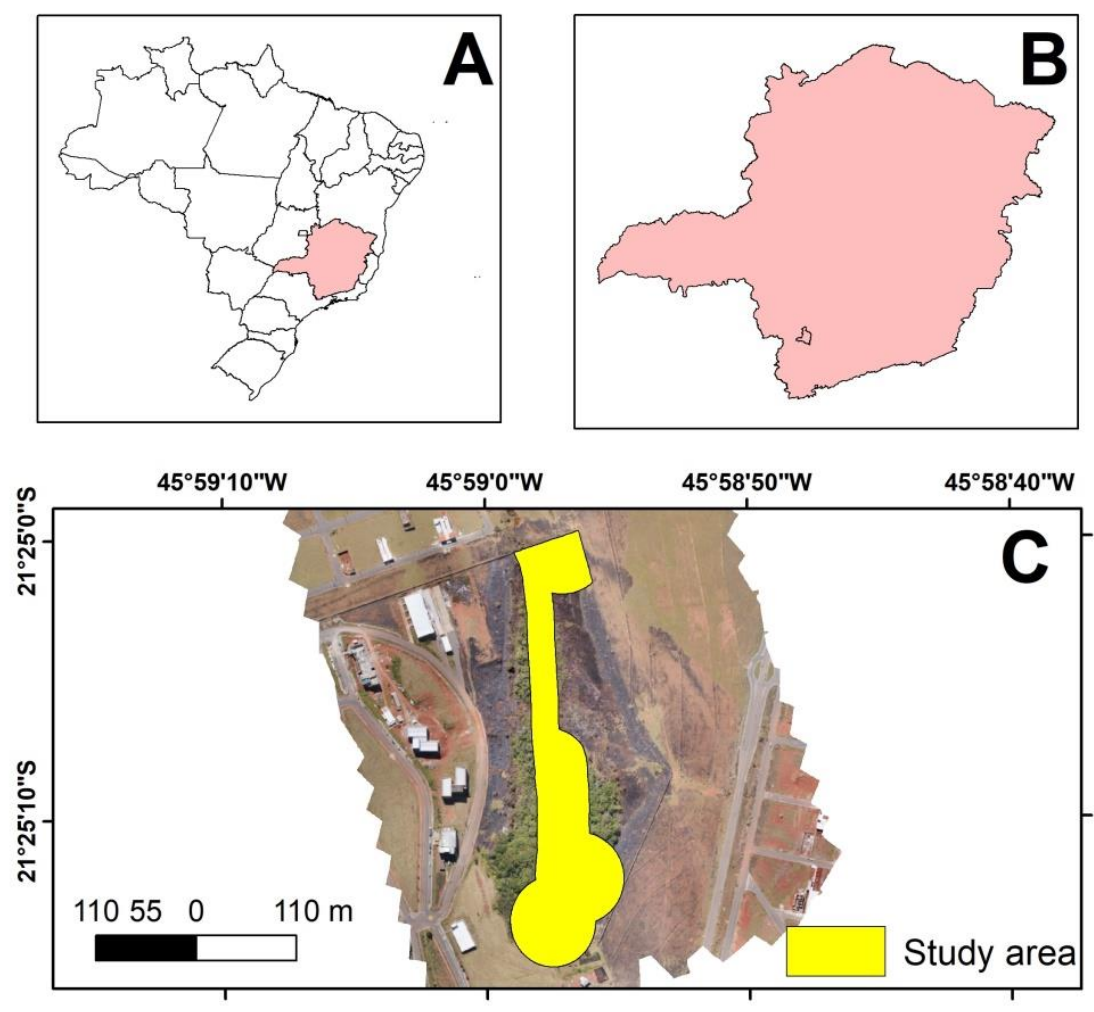

Figure 1. Location of the study area: A- Brazil and Minas Gerais; B- Minas Gerais and Alfenas; C- RGB Image of the study area.

The geological framework is constituted by garnet-biotite-gneisses and biotite gneisses with quaternary soil covers, with fluvial deposits of gravel, sand, and clay (Pinto et al., 2020). The soils are mainly composed of Latosols and Indiscriminate Floodplain Soils (Marangon et al., 2017). The climate, according to Köppen's classification, is Tropical Mesothermal (Cwb) (Sparovek et al., 2007), with two well-defined seasons: hot and humid summer and dry and cold winter.

The dominant riparian vegetation in the permanent preservation area belongs to the Atlantic Forest biome, which has a history of intense devastation 
since the beginning of the occupation of Brazilian territory, in the $16^{\text {th }}$ century (Carvalho et al., 2007). Specifically, the area comprises the presence of at least three mapped springs, with three $1^{\mathrm{st}}$ and one $2^{\text {nd }}$ order channels (Marangon et al., 2017).

To obtain the images of the study area by the fires, Drone Phantom 4 with an RGB sensor, a Sony EXMOR camera, which captures images in real colours, was used. The flights were carried out in early August, September, and November 2019 at $100 \mathrm{~m}$ altitude and with $40 \%$ frontal and lateral image overlap.

The flights were planned and executed in Pix4DCapture software. The images obtained were processed using Structure-from-Motion (SfM) software Agisoft Photoscan Professional ${ }^{\circledR}$ v.1.2.7. A reconstructed mesh surface was derived from the point cloud using the automatic point classification procedure based on maximum angle, maximum distance, and pixel size. Then the image was orthorectified and georeferenced (Panagiotidis et al., 2017).

Then, maps of land use and occupation inside the preservation area were made using ArcGIS 10.5 software. Manual classifications were carried out for the months of August, September, and November 2019. Then, area calculations were made for the respective classifications. Finally, the variation of land use and occupation in the period was evaluated, to verify the evolution of the regeneration of the area affected by the fire (Parsipour et al., 2019).

Three sites in the impacted area were selected as fire mapping standards. These sites also served as control points for diagnosing the evolution of vegetation regeneration. Such places were grouped in a figure and evaluated according to the scientific literature on the subject (Cesljar et al., 2021; Ganaie et al., 2021).

Finally, the environmental and socioeconomic impacts of forest fires were evaluated, with emphasis on the adoption of strategies to combat and control clandestine and/or criminal fires in Brazil.

\section{RESULTS AND DISCUSSION}

This research produced the land use and occupation map in the area affected by the fire for the months of August, September and November 2019, the dimensions of land uses for the months studied, the rates of variation of land uses in the period, and fire mapping patterns.

Figure 2 illustrates three areas that, due to their unique characteristics, can contribute to remote detection methods for areas affected by fires. The figures were grouped and organized into three classes, A, B and C, to facilitate the interpretation of the obtained features. 

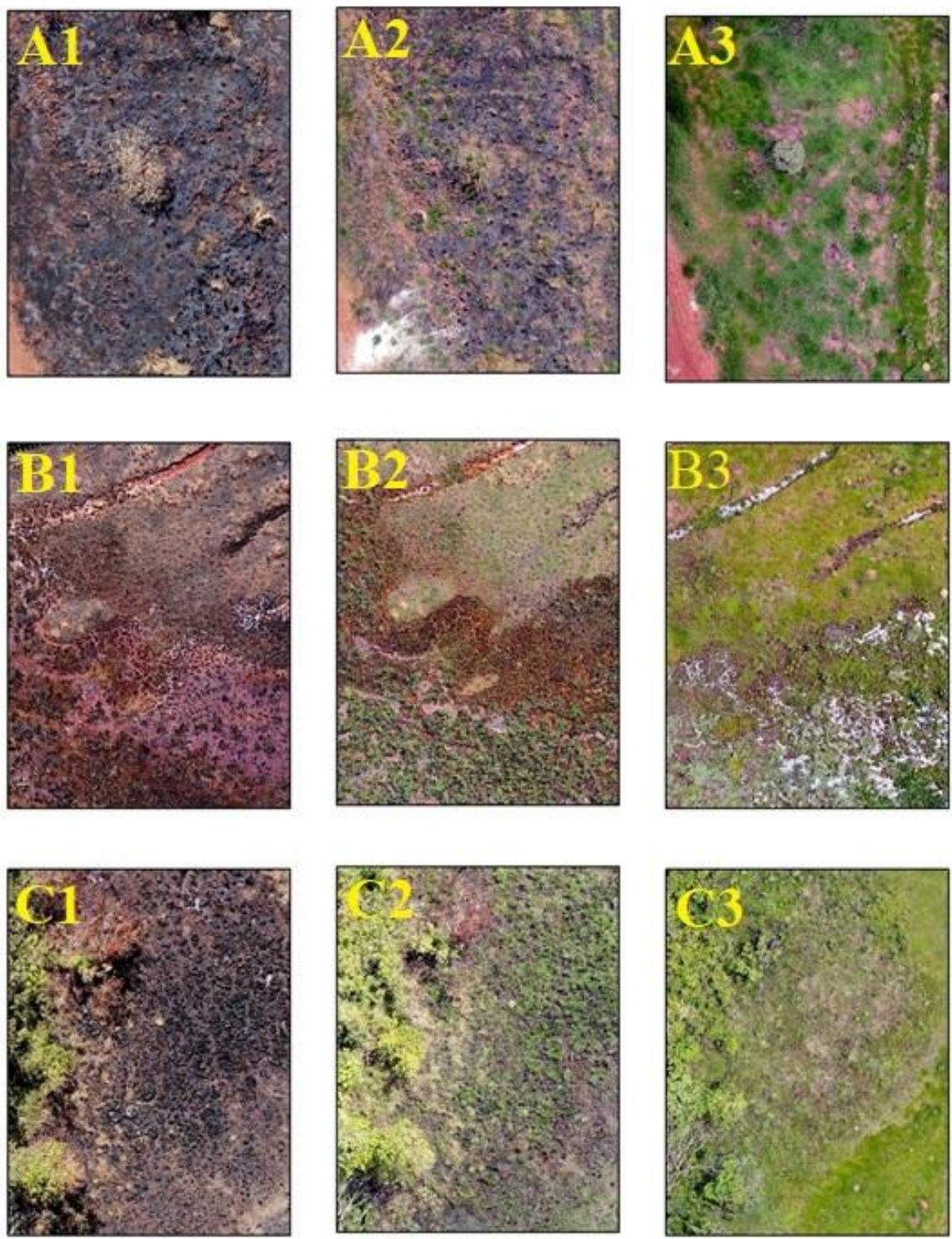

Figure 2. Areas impacted by fires. A1: Countryside area affected by fire in August 2019; A2: Countryside area affected by fire in September 2019; A3: Countryside area affected by fire in November 2019; B1: Floodplain area affected by fire in August 2019; B2: Floodplain area affected by fire in September 2019; B3: Floodplain area affected by fire in November 2019; C1: Forest fragment edge area affected by fire in August 2019; C2: Forest fragment edge area affected by fire in September 2019; C3: Forest fragment edge area affected by fire in November 2019. 
In Figure 2 (A1, A2 and A3 and $\mathrm{C} 1, \mathrm{C} 2$ and $\mathrm{C} 3$ ) the area had a very rapid regeneration process and that was recorded for the period of just three months, no fire scars were identified. The full recovery of the landscape after just three months could indicate the possibility of using controlled forest fires for landscape management. Even in absolutely controlled conditions, it is necessary to follow safety procedures, such as specialized technical monitoring, prior study of the species exposed to the procedure and the presence of fire brigades with training and equipment to avoid extreme events of loss of fire from control conditions.

The areas B1, B2 and B3 (Figure 2) illustrate the floodplain impacted by fire. Visual analysis of the images allows the identification of wetlands in B1 and B2 in brown and orange tones, indicating that the fire contributed to promote erosive processes and sediment transport from springs and drainage channels. Thus, as vegetation regeneration evolves, the water regains its colourless visual appearance.

Forest fires cause loss of soil and water quality, in addition to reducing the quantity and diversity of microorganisms, reducing macro fauna, and also causing direct effects in the increase in sediment production, as pointed out by GironaGarcía et al. (2021).

The recent fires in the Amazon region are criminal and difficult to monitor and control due to their extent and access difficulties. In this context, any combat and inspection action is compromised when there is no interest of the different levels of government in articulating actions to combat fires and their adverse effects, contrary to world public opinion (Girona-García et al., 2021). Thus, the absence of public and inspection policies exposes the population to risks arising from fires, such as poisoning, severe lung diseases, especially in children and the elderly, and burns (Ignotti et al., 2007). In periods of recurrent fires, such as recent ones in Brazil, hospital admission rates increase and burden the public health system. In 2020, in particular, the COVID-19 pandemic began, which further increased the pressure on the public health system (Henderson, 2020). This theme of forest fires is recurrent and has been debated for many years (Ignotti et al., 2007), with no prospects for improving this situation so far. Historically, governments have not taken the necessary measures for economic agents to comply with environmental legislation. The Amazon biome is increasingly threatened by the absence of effective public policies, whose consequences threaten life on the planet and the future of humankind.

The monitoring of land use and occupation in the period is illustrated in Figure 3. It was possible to identify the areas impacted by fire within the permanent preservation areas. Such information is essential for the preparation of environmental recovery plans. As shown in Figures $3 \mathrm{~A}, \mathrm{~B}$ and $\mathrm{C}$, during the period there was a gradual reduction in the areas affected by the fire.

In the short period covered, the formation of new forest fragments was not identified. However, regeneration areas were identified, mainly in November (Figure 3C), after a short period of rain between September and October. 


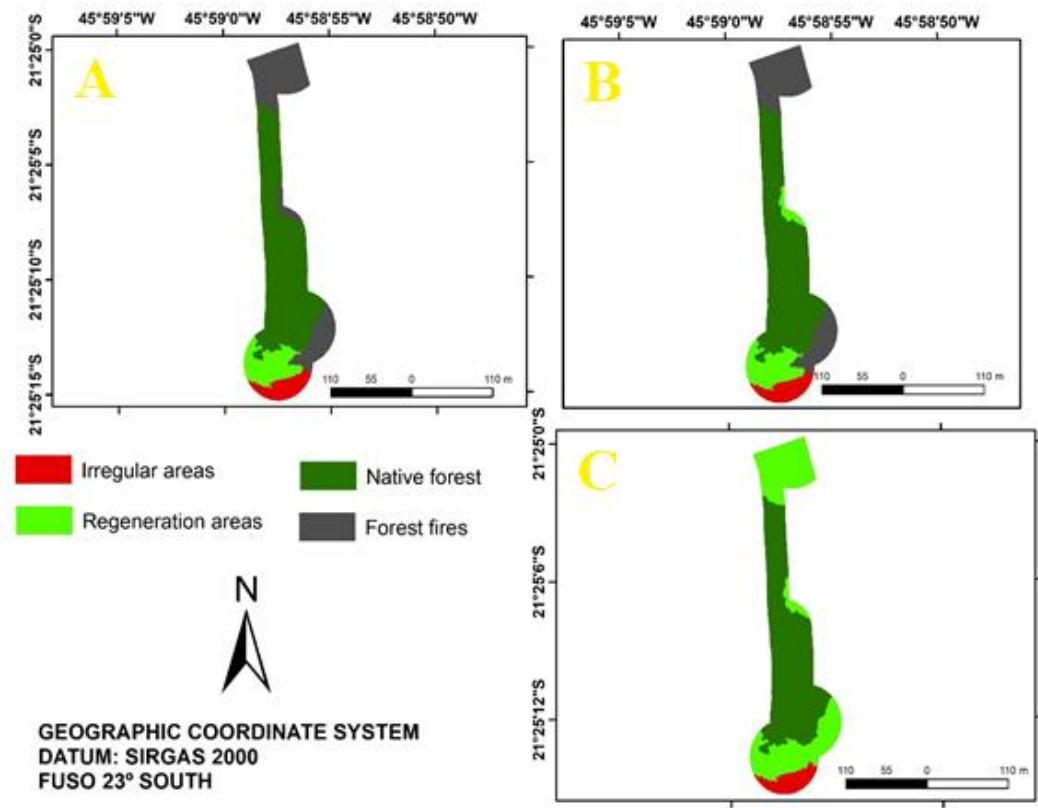

Figure 3. Land use and occupation maps in an permanent preservation area affected by fire. A: August; B: September; C: November.

The distribution of the areas of the respective land uses show that the most expressive land use is the Native Forest, which did not change over the period. Then, the most expressive use identified were the areas burned, which were reduced to zero between August and November 2019 as illustrated in Figure 2 and 3. In contrast to the reduction in areas burned, there was an increase of the areas of regeneration. During the period covered, there was no change in the areas classified as irregular, as they are occupied with infrastructure within the permanent preservation area.

Over the years, forest fires have devastated Brazilian biomes. Effective public policies to combat and prevent forest fires are practically non-existent and the lack of inspection and punishment for legal infractions end up encouraging clandestine forest fires. Management and inspection agencies are unable to adequately fulfil their role due to lack of infrastructure, specialized technical staff and investment in the development of firefighting policies (Sobrinho and Ramos Júnior, 2020).

In this context, about $90 \%$ of fires in Brazil are forest fires, mainly in the management of pasture areas for agricultural production, with direct ecological damage to Brazilian biomes (Sobrinho and Ramos Júnior, 2020). Among those most affected by forest fires, we can highlight the Cerrado (Savanna), Pantanal and Amazon Biomes. Theses biomes are strategic for the maintenance of biodiversity and good results in environmental quality indicators (Sobrinho and Ramos Júnior, 2020). 
This intense conversion of forest to pasture and agricultural areas has a direct impact on the emission of greenhouse gases from the carbon state in the region's biomass and soils. The Amazon region, as highlighted by Fearnside (2018), has significant carbon stocks that can be released as greenhouse gases when the native forest is converted for any other use. Despite uncertainties in carbon stock estimates, it is necessary to expand research on the impacts of converting native forest to other uses.

Fires larger than 50 ha grew from 32\% in 2016 to $46 \%$ in 2019 in southwestern Amazonia, suggesting the authorities' inefficiency or lack of interest in enforcing environmental and forest fire fighting laws. Private properties accounted for $1 / 5$ of the burned areas (Silva et al., 2021).

According to Silva et al. (2021), to prevent deforestation and forest fires, authorities should promote strategic actions and allocate human and material resources for environmental surveillance and law enforcement. Thus, the authorities should organize a forest fire management plan in vulnerable areas aiming at environmental sustainability in the Cerrado (Savanna), Caatinga, Amazon and Atlantic Forest biomes.

In addition, it is necessary to seek socioeconomic development that reflects the advantages of maintaining and expanding the native forests of Brazilian biomes, favoring a society based on the provision of environmental services and abandoning the outdated vision of the colonizer, which is a predatory and inconsistent vision with main challenges posed by climate change (Fearnside, 2018).

\section{CONCLUSIONS}

The equipment used fulfilled the objective of being useful for detection of areas affected by fires, allowing the identification of mapping patterns that can be used as a reference for automated mapping.

The visual analysis of the images allowed us to conclude that fires directly impacted the quality of the water, erosion processes and sediment production.

The methodological procedure used made it possible to monitor the evolution of land use in the area affected by fire and to monitor the development of the initial process of regeneration of the burned area.

Strategic actions by the state administration are necessary and urgent to fight clandestine forest fires and to monitor the application of Brazilian environmental legislation.

\section{ACKNOWLEDGEMENTS}

To the Coordenação de Aperfeiçoamento de Pessoal de Nível Superior (CAPES) for granting a scholarship to the first author. To the Fundação de Amparo à Pesquisa do Estado de Minas Gerais (FAPEMIG) for the scholarship offered to the fifth author. Study was partially funded by the CAPES - Financial Code 001. The authors are grateful to the anonymous reviewers and the Editorial team for their insightful comments and suggestions. 


\section{REFERENCES}

Biazatti, L.D., Fiedler, N.C., Ramalho, A.H.C., Pereira, D.P., Dos Santos, A.R., Moreira, G.L. (2020): Influência do uso e ocupação da terra no risco de ocorrência de incêndios florestais. Agropecuária Científica no Semiárido, 16(4): 155-160.

Carvalho, F.A., Nascimento, M.T., Braga, J.M.A. (2007): Estrutura e composição florística do estrato arbóreo de um remanescente de mata atlântica submontana no município de Rio Bonito. RJ, Brasil (Mata Rio Vermelho). Revista Árvore, 31(4): 717-730.

Cesljar, G., Dordevic, I., Brasanac-Bosanac, L., Eremija, S., Mitrovic, S., CirkovicMitrovic, T., Lucic, A. (2021): Determination of forest decline due to the action of dominant stress factor through monitoring of defoliation - case study of Maljen, Serbia. Agriculture and Forestry, 67(2): 211-226.

Chalise, D.; Kumar, L.; Spalevic, V.; Skataric, G. (2019): Estimation of Sediment Yield and Maximum Outflow Using the IntErO Model in the Sarada River Basin of Nepal. Water 2019, 11: 952. https://doi.org/10.3390/w11050952

Eugenio, F.C., Dos Santos, A.R., Fiedler, N.C., Ribeiro, G.A.,Da Silva, A.G., Dos Santos, A.B., Paneto, G.G., Schettino, V.R. (2016): Applying GIS to develop a model for forest fire risk: A case study in Espírito Santo, Brazil. Journal of Environmental Management, 173(1):65-71.

Fearnside, P.M. (2018): Brazil's Amazonian forest carbon: the hey to Southern Amazonia's significance for global climate. Regional Environmental Change, 18(1): 47-61.

Felix, F.C., Spalevic, V., Curovic, M., Mincato, R.L. (2021): Comparing pixel- and object- based forest canopy gaps classification using low-cost unmanned aerial vehicle imagery. Agriculture and Forestry, 67(3): 19-29

Ganaie, T.A., Jamal, S., Ahmad, W.S. (2021): Changing land use/landcover patterns and growing human population in Wular catchment of Kashmir Valley, India. Geojournal, 86(5): 1589-1606.

Girona-García, A., Vieira, D.C.S., Silva, J., Fernández, C., Robichaud, P.R., Keizer, J.J. (2021): Effectiveness of post-fire soil erosion mitigation treatments: A systematic review and meta-analysis. Earth-Science Reviews, 217(1), 1-20.

Henderson, S.B. (2020): The COVID-19 Pandemic and Wildfire Smoke: Potentially Concomitant Disasters. American Journal of Public Health, 10(4): 1140-1142.

Hysa, A., Spalevic, V. (2020): Testing NDVI, Tree Cover Density and Land Cover Type as Fuel Indicators in the Wildfire Spread Capacity Index (WSCI): Case of Montenegro. Notulae Botanicae Horti Agrobotanici Cluj-Napoca, 48(4): 23682384.

Hysa, A.; Spalevic, V.; Dudic, B.; Roșca, S.; Kuriqi, A.; Bilașco, Ș.; Sestras, P. (2021): Utilizing the Available Open-Source Remotely Sensed Data in Assessing the Wildfire Ignition and Spread Capacities of Vegetated Surfaces in Romania. Remote Sens. 2021, 13, 2737. https://doi.org/10.3390/rs13142737

Ignotti, E., Hacon, S.S., Silva, A.M.C., Junger, W.L., Castro, H. (2007): Efeitos das queimadas na Amazônia: métodos de seleção dos municípios segundo indicadores de saúde. Revista Brasileira de Epidemiologia, 10(4): 453-464.

Kalehhouei, M., Hazbavi, Z., Spalevic, V., Mincato, R.L., Sestras, P. (2021): What is smart watershed management? Agriculture and Forestry, 67(2): 195-209.

Marangon, F., Servidoni, L.E., Costa, C.W., Spalevic, V., Mincato, R.L. (2017): Land use and groundwater resources resources potential vulnerability to contamination. Agriculture and Forestry, 65(1): 211-222.

Panagiotidis, D., Abdollahnejad, A., Surovy, P., Chiteculo, V. (2017): Determing tree height and crown diameter from high-resolution UAV imagery. International Journal Remote Sensing, 38(8-10): 2392-2410. 
Pinto, G.S., Servidoni, L.E., Lense, G.H.E., Moreira, R.S., Mincato, R.L. (2020): Estimativas das perdas de solo por erosão hídrica utilizando o Método da Erosão Potencial. Revista do Departamento de Geografia, 39(1): 62-71.

Sarra, S.R. \& Mülfarth, R.C.K. (2021): Impactos das queimadas da região Centro-Oeste do Brasil sobre as cidades do Estado de São Paulo. Brazilian Journal of Development 7(5): 51237-21257.

Sestras, P., Bilașco, Ș., Roșca, S., Hysa, A., Spalevic, V. (2021): Geodetic and UAV monitoring in the sustainable management of shallow landslides and erosion of a susceptible urban environment. Remote Sensing, 13(3): 1-29, 385

Sestras, P.; Rosca, S.; Bilasco, S.; Nas, S.; Buru, SM.; Spalevic, V.; Sestras, AF. (2020): Feasibility Assessments Using Unmanned Aerial Vehicle Technology in Heritage Buildings: Rehabilitation-Restoration, Spatial Analysis and Tourism Potential Analysis. Sensors, 20(7): 2054-2076.

Sestras, P.; Sălăgean, T.; Bilașco, S.; Bondrea, M.V.; Naș, S.; Fountas, S.; Cîmpeanu, S.M. Prospect of a GIS based digitization and 3D model for a better management and land use in a specific micro-areal for crop trees. Environ. Eng. Manag. J. 2019, $18,1269-1277$.

Silva, S.S., Oliveira, I., Morello, T.F., Anderson, L.O., Karlokoski, A., Brando, P.M., Melo, A.W.F., Costa, J.G., Souza, F.S.C., Silva, I.S., Nascimento, E.S., Pereira, M.P., Almeida, M.R.N., Alencar, A., Aragão, L.E.O.C., Brown, I.F., Graça, P.M.L.A., Fearnside, P.M. (2021): Burning in shouthwestern Brazilian Amazonia, 2016-2019. Journal of Environmental Management, 286(1): 1-10.

Sobrinho, C.J.B. \& Ramos Júnior, D.V. (2020): As queimas e as queimadas no Tocantins: o município de maior registro da série histórica de focos de calor ativos. (2020). Revista Ibero Americana de Ciências Ambientais, 11(1): 378-390.

Spalevic, V.; Barovic, G.; Vujacic, D.; Curovic, M.; Behzadfar, M.; Djurovic, N.; Dudic, B.; Billi, P. (2020): The Impact of Land Use Changes on Soil Erosion in the River Basin of Miocki Potok, Montenegro. Water 2020, 12: 2973.

Spalevic, V.; Djurovic, N.; Mijovic, S.; Vukelic-Sutoska, M.; Curovic, M. (2013): Soil Erosion Intensity and Runoff on the Djuricka River Basin (North of Montenegro). Malaysian Journal of Soil Science, 17: 49-68.

Sparovek, G., Van Lier, Q.J., Dourado Neto, D.D. (2007): Computer assisted Koppen climate classification: a case study for Brazil. International Journal of Climatology, 27(1): 257-266.

Stefanidis, S.; Alexandridis, V. (2021). Precipitation and Potential Evapotranspiration Temporal Variability and Their Relationship in Two Forest Ecosystems in Greece. Hydrology 2021, 8, 160. https://doi.org/10.3390/hydrology8040160

Stefanidis, S.; Chatzichristaki, C. Stefanidis, P. (2021): An ArcGIS toolbox for estimation and mapping soil erosion. Journal of Environmental Protection and Ecology 22(2): 689-696

Tebaldo, A.L.C., Fiedler, N.C., Juvanhol, R.S., Dias, H.M. (2013): Ações de combate aos incêndios florestais nas unidades de conservação estaduais do Espírito Santo. Floresta e Ambiente, 20(3): 538-549. 